Bangladesh J. Plant Taxon. 24(1): 33-38, 2017 (June)

(C) 2017 Bangladesh Association of Plant Taxonomists

\title{
A NEW SPECIES OF ISCHAEMUM L. (POACEAE) FROM KERALA, INDIA
}

\author{
C.N. Sunil, V. Nithya Madhanan, C.R. Remya Krishnan, V.V. Naveen KumaR', \\ M.S. Simi AND K.J. JYOTHI \\ Post Graduate \& Research Department of Botany, S.N.M. College, Maliankara, \\ Ernakulam District, Kerala, India
}

Key words: Ischaemum; new species; Poaceae; Kerala; India

\begin{abstract}
Ischaemum sreenarayanii, a new species of Ischaemum L. is described and illustrated with detailed notes on distribution, conservation status and phenology. The new species is similar to I. santapaui and $I$. nairii but differs in number of attributes having up to $1.3 \mathrm{~cm}$ long filiform tip of the leaf apex, villous pseudopetiole of upper leaves and 4-6 conspicuous annular transverse ridges and winged margins of the sessile spikelet.
\end{abstract}

\section{Introduction}

The genus Ischaemum L. belongs to the family Poaceae. All the species of Ischaemum are distributed in Warm and tropical regions of the world especially in Asia (Mabberley, 2008) with about 81 species (Plant list, 2013).

The genus Ischaemum was treated in different ways by various authors in India. Sur (2001) recognized 51 taxa in India. Later, Singh and Rao (2008) proposed changes in status for some species and new combinations. Thus in their study, only 36 taxa were reported including two new additions to the Indian flora. Srivastava and Nair (2010) worked on Indian Ischaemum and reported 56 taxa, indicating that they overlook the changes made by Sing and Rao (2008). In India, the genus is mostly represented in Southern Western Ghats, especially in Kerala. Sreekumar and Nair (1991) identified 28 species, 3 varieites and 2 sub-varieties including 11 new species. Nayar et al. (2006) included 39 taxa of Ischaemum in 'Flowering plants of Kerala' and Srivastava and Nair (2010) reported 40 taxa from Kerala state. After the publication of 'Genus Ischaemum (Poaceae) in India' (Srivastava and Nair, 2010), two new species were described from India viz. I. kasaragodensis Dileep and G.G. Nair (Dileep and Geetha, 2015) and I. sayajiraoi Raole and R.J Desai (Vinay et al., 2011). Hence the total number of Ischaemum in India becomes 58 and that of Kerala is 41.

During the floristic studies in central Kerala, authors collected interesting specimens of Ischaemum from wetland areas of Thrissur and Palakkad districts of Kerala. Critical studies using relevant literature and type materials of similar species revealed its novelty and distinctness from the hitherto known species and described here as new species Ischaemum sreenarayanii.

Ischaemum sreenarayanii Sunil, Nithya and Remya sp.nov.

(Figs 1 \& 2).

Diagnosis: Ischaemum sreenarayanii is similar to Ischaemum santapaui Bor. in its tall and robust habit with stilt rooted lower nodes, glabrous glumes, narrowed and tapering base of lower leaves and rounded base of upper leaves but differs in having large bulbous-pilose leaves with

${ }^{1}$ Corresponding author. Email: naveenkumar2389@gmail.com

DOI: http://dx.doi.org/10.3329/bjpt.v24i1.33003 


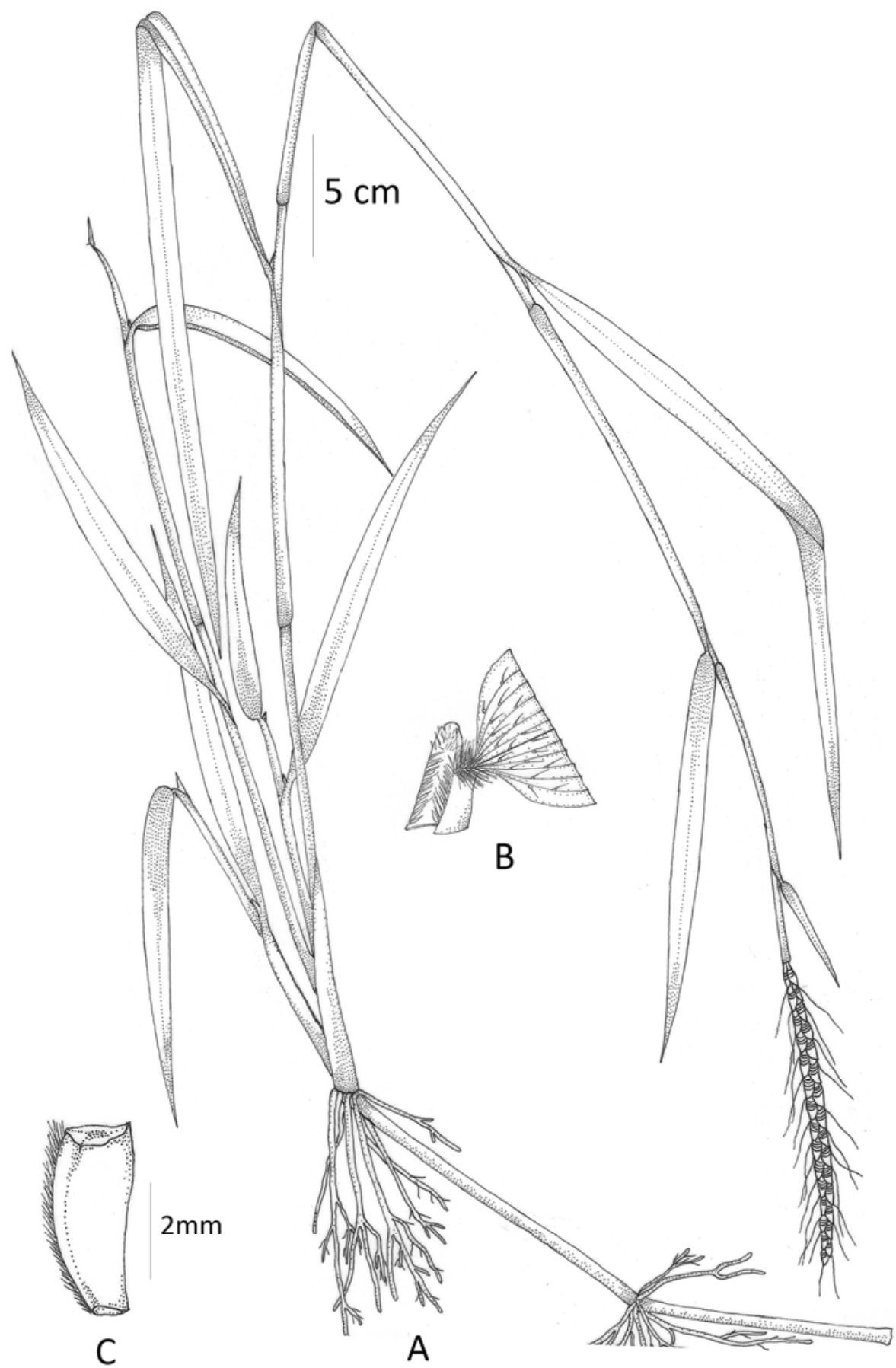

Fig. 1. Ischaemum sreenarayanii Sunil, Nithya and Remya: A. Habit; B. A portion of upper leaf base showing ligule \& villous Pseudopetiole; C. Rachis. 


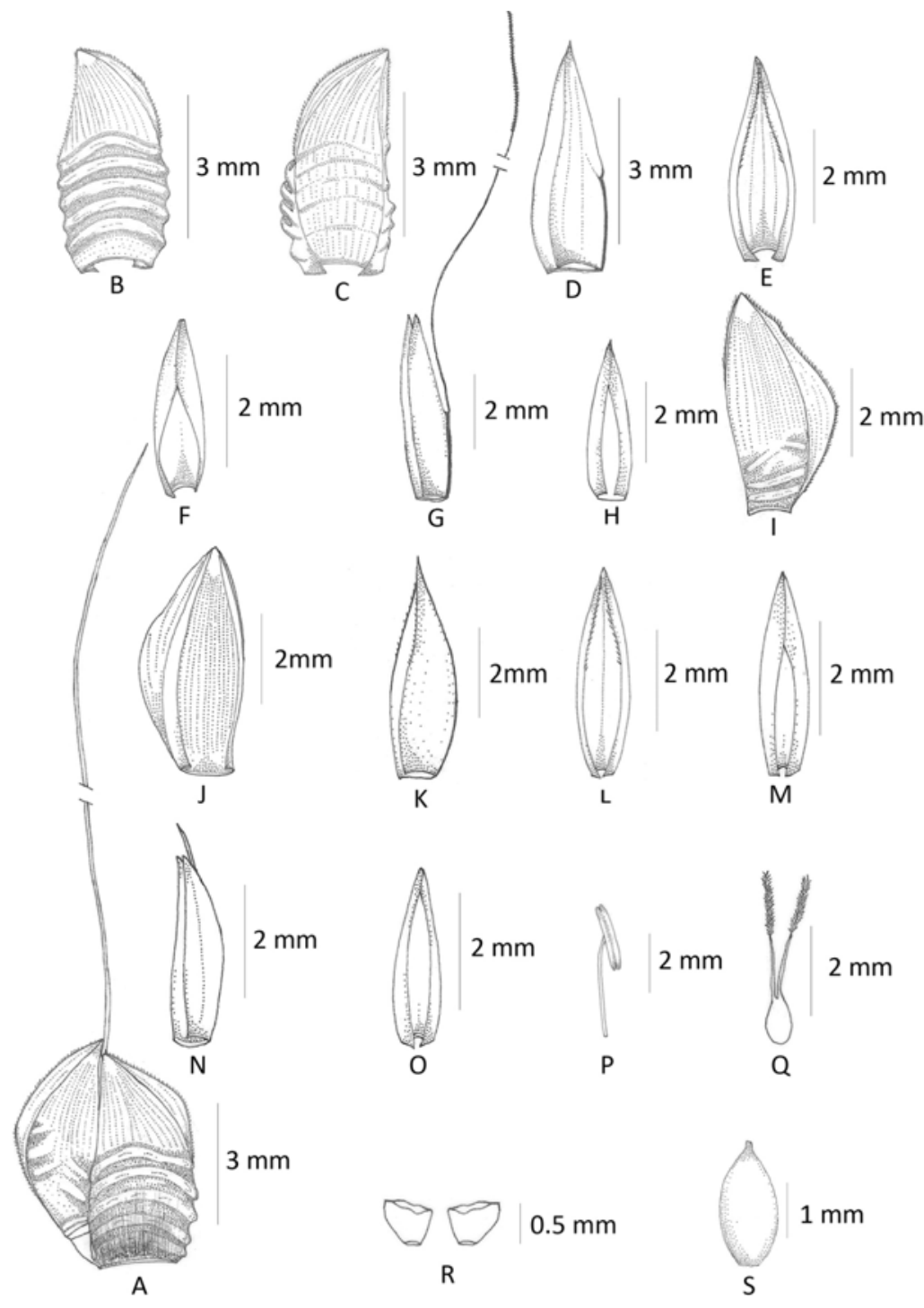

Fig. 2. Ischaemum sreenarayanii Sunil, Nithya and Remya: A. Paired spikelet; B-H Sessile spikelet: B \& C. Dorsal \& ventral view of Lower glume; D. Upper glume; E. Lower lemma; F. Lower palea; G. Upper lemma; H. Upper palea; I-O Pedicelled spikelet: I\&J. Dorsal \& ventral view of Lower glume; K. Upper glume; L. Lower lemma; M. Lower palea; N. Upper lemma; O. Upper palea; P. Stamen; Q. Pistil; R. Lodicules; S. Grain.

long filiform apex, villous pseudopetiole on upper leaves, long and appressed raceme, lower glume of the sessile spikelet with 4-6 conspicuous annular transverse ridges and winged margins, long awned upper lemma of sessile spikelet and well developed pedicelled spikelets. The new species is also shows some similarities with Ischaemum nairii Nair Sreekumar in its robust habit, tubercle based hairy leaves, glabrous glumes but differs in having stilt root, leaf apex with up to $1.3 \mathrm{~cm}$ long filiform tip, villous pseudopetiole on upper leaves, 4-6 conspicuous upwardly 
directed annular transverse ridges and winged margins on one side of lower glume of sessile spikelet, shorter lower palea of sessile spikelet, long upper lemma of sessile spikelet with 18-24 $\mathrm{mm}$ long awn, pedicel 1.0-1.5 mm long and less than one-third length of lower glume of sessile spikelet.

Type: INDIA, Kerala: Thrissur district, Kombazha, \pm 11 m, $10^{0} 34^{\prime} 38.5^{\prime \prime} \mathrm{N} 76^{0} 23^{\prime} 50.0^{\prime \prime} \mathrm{E}, 8$ December 2015, Sunil \& Nithya 9007 (Holotype: MH!; Isotypes: CALI!, SNMH!).

Densely tufted and deep-rooted perennials. Culms robust, erect to decumbent, up to $160 \mathrm{~cm}$ long, 2.5-7.0 mm across and stilt rooted at the base, generally reddish-brown, glaucous below the node; nodes densely villous. Leaves all along the culm; blade 8-40 × 1.0-2.7 cm, linear-lanceolate to linear-elliptic, lower ones tapering into a short pseudopetiole, upper ones rounded with densely villous up to $3 \mathrm{~mm}$ long pseudopetiole, scaberulous on margins, acuminate with up to $1.3 \mathrm{~cm}$ long filiform apex, mid-vein thickly prominent below, canaliculate above, bulbous-pilose on both surfaces; ligule sub-coriaceous, $1-10 \mathrm{~mm}$ long, oblong, rounded to truncate at apex, sparsely pilose; sheath 8-20 cm long, rounded on the back, bulbous-pilose along margins. Inflorescence of two racemes, exserted, 8-14 cm long, appressed to give the appearance of a single raceme; joints of rachis 3- $4 \times 1.5-2.0 \mathrm{~mm}$, triquetrous, clavate-turbinate to linear-clavate, crustaceous, fistular, strawcoloured, ciliate on the outer angle and glabrous otherwise. Sessile spikelet 5.0-5.5 $\times 2.0-2.2$ $\mathrm{mm}$, elliptic-oblong, awned, lower floret male, upper floret bisexual; callus ca. $0.5 \mathrm{~mm}$ long, longvillous with hair up to $2 \mathrm{~mm}$ long. Lower glume 4.5-5.5 $\times 2.0-2.2 \mathrm{~mm}$, elliptic-oblong, acute at apex, crustaceous in the lower $1 / 2-2 / 3$ regions with 4-6 conspicuous upwardly directed annular transverse ridges, thickly coriaceous and smooth above, laterally2- keeled with incurved margins and the keel winged on one side towards apex, scaberulous on the margin of the wing, weakly 1113-nerved. Upper glume 4.5- 5.5 × 1.8-2.0 mm, lanceolate, boat- shaped, acute at apex, keeled on back and humped below middle, shortly incurved on sparsely ciliate margins, coriaceous, strawcoloured, 5-7-nerved. Lower lemma 4-5 × 1.2-1.6 mm, elliptic- lanceolate, acute at apex, hyaline, 3 - nerved, margins incurved and shortly ciliate on upper half. Lower palea $3-4 \times 1.0-1.2 \mathrm{~mm}$, elliptic-lanceolate, obtuse to truncate at apex, hyaline, 2-nerved, infolded along the nerves and minutely scaberulous along keel. Upper lemma $4.0-4.5 \times 1.2-1.4 \mathrm{~mm}$, elliptic, cleft to the middle with acuminate lobes, awned from the sinus, hyaline, glabrous, 3-nerved; awn 18-24 mm long, geniculate with a column of $8-10 \mathrm{~mm}$ long, scaberulous except on the chestnut brown column. Upper palea 2.5-3.0 $\times 1.0-1.2 \mathrm{~mm}$, ovate-lanceolate, acuminate at apex, hyaline, 2-nerved, infolded along the nerves. Pedicelled spikelet 4.5-5.5 $\times$ 2.0-2.5 mm, oblong-elliptic, acute at apex, with rudimentary awn or awnless; lower floret male or empty, upper bisexual; pedicels 1.0-1.5 $\times$ ca. $1 \mathrm{~mm}$, triquetrous, long ciliate on the outer angle and glabrous otherwise. Lower glume 4.3-5.4 $\times$ 2.0-2.5 mm, obliquely oblong-elliptic, acute at apex, thickly sub - crustaceous with $2-4-$ annular transverse ridges or nodulose in the lower half, coriaceous-herbaceous above, laterally keeled with incurved margins and the keel broadly winged on one side and narrowly winged on the other, scaberulous on the margin of the wing, 11-13- nerved, glabrous. Upper glume 4-5 × 1.4$1.6 \mathrm{~mm}$, lanceolate, boat- shaped, acute at apex, coriaceous, straw -coloured, minutely keeled on back, not humped, shortly incurved on margins with the margins sparsely ciliate or glabrous, 5-7nerved. Lower lemma 3.5-4.5 $\times$ ca. $1 \mathrm{~mm}$, elliptic-lanceolate, acute to acuminate at apex, hyaline, 3 - nerved, incurved on the margins, minutely scabrid on keels and sparsely ciliate on the margins. Lower palea 3-4 × ca. $1 \mathrm{~mm}$, elliptic-lanceolate, acute at apex, hyaline, 2- nerved, incurved along the nerves, minutely scabrid on keels towards apex. Upper lemma 2.7-3.4 $\times$ ca. $1 \mathrm{~mm}$, ovatelanceolate, shortly notched at apex and imperfectly awned with an awn up to $2 \mathrm{~mm}$ long from the sinus or entire and unawned, hyaline, glabrous, 3- nerved. Upper palea 2-3 $\times 1.0-1.2 \mathrm{~mm}$, ovate- 
Table 1. Distinguishing characters of Ischaemum sreenarayanii from Ischaemum santapaui Bor. and Ischaemum nairii V.J. Nair and P.V. Sreekumar.

\begin{tabular}{|c|c|c|c|}
\hline Characters & I. santapaui & I. sreenarayanii sp. nov. & I. nairii \\
\hline Stilt root & Present & Present & Absent \\
\hline Leaves & $\begin{array}{l}0.4-1.0 \mathrm{~cm} \text { wide, glabrous, } \\
\text { scabrid on both side, acute at } \\
\text { apex, upper ones shallowly } \\
\text { cordate at the base without a } \\
\text { villous pseudopetiole }\end{array}$ & $\begin{array}{l}1.0-2.7 \mathrm{~cm} \text { wide, bulbous } \\
\text { - pilose on both sides, } \\
\text { acuminate with up to } 1.3 \\
\mathrm{~cm} \text { long filiform tip at } \\
\text { apex, upper ones rounded } \\
\text { at the base with up to } 3 \\
\text { mm long densely villous } \\
\text { pseuodopetiole }\end{array}$ & $\begin{array}{l}1-2 \mathrm{~cm} \text { wide, densely } \\
\text { villous with tubercle } \\
\text { based hairs, acuminate, } \\
\text { upper ones round or } \\
\text { shallowly cordate } \\
\text { without a villous } \\
\text { pseudopetiole }\end{array}$ \\
\hline Joints of rachis & $\begin{array}{l}\text { Long hairy on one angle, } \\
\text { smooth and glabrous on the } \\
\text { other two }\end{array}$ & $\begin{array}{l}\text { Ciliate on the outer angle } \\
\text { and glabrous otherwise }\end{array}$ & $\begin{array}{l}\text { Long villous along } \\
\text { margins and dorsal } \\
\text { angles }\end{array}$ \\
\hline Raceme & $\begin{array}{l}\text { In fascicles, upto } 7.5 \mathrm{~cm} \\
\text { long, divergent }\end{array}$ & $\begin{array}{l}\text { Not fascicled, } 8-14 \mathrm{~cm} \\
\text { long, appressed }\end{array}$ & $\begin{array}{l}\text { Not fascicled, } 5-12 \mathrm{~mm} \\
\text { long, appressed }\end{array}$ \\
\hline $\begin{array}{l}\text { Lower glume } \\
\text { of the } \\
\text { sessile spikelet }\end{array}$ & $\begin{array}{l}\text { Coriaceous, flat in the lower } \\
3 / 4 \text { region, herbaceous } \\
\text { above, margins not winged, } \\
10-11 \text { - nerved }\end{array}$ & $\begin{array}{l}\text { Crustaceous in the lower } \\
1 / 2-2 / 3 \text { regions with } 4-6 \\
\text { conspicuous upwardly } \\
\text { directed annular transverse } \\
\text { ridges, coriaceous above, } \\
\text { margins winged on one } \\
\text { side towards apex, } 11-13- \\
\text { nerved }\end{array}$ & $\begin{array}{l}\text { Crustaceous in the lower } \\
1 / 3-2 / 3 \text { regions with } \\
\text { several side nodules } \\
\text { joined by sharp ridges, } \\
\text { scabrid above, not } \\
\text { winged, } 9-11-\text { nerved }\end{array}$ \\
\hline $\begin{array}{l}\text { Upper glume of } \\
\text { the } \\
\text { sessile spikelet }\end{array}$ & $\begin{array}{l}\text { Mucronate at apex, scabrid } \\
\text { on dorsal surface, rounded } \\
\text { on back below middle }\end{array}$ & $\begin{array}{l}\text { Acute, not mucronate at } \\
\text { apex, not scabrid on dorsal } \\
\text { surface, humped on back } \\
\text { below middle }\end{array}$ & $\begin{array}{l}\text { Acute, tip minutely } \\
\text { winged and scabrid, } \\
\text { smooth, } \\
\text { coriaceous, humped on } \\
\text { back below middle }\end{array}$ \\
\hline $\begin{array}{l}\text { Lower palea of } \\
\text { the sessile } \\
\text { spikelet }\end{array}$ & Ca. $3.0 \mathrm{~mm}$ long & 3-4 mm long & 4.5-5.4 $\mathrm{mm}$ long \\
\hline $\begin{array}{l}\text { Upper lemma } \\
\text { of Sessile } \\
\text { spikelet }\end{array}$ & $\begin{array}{l}\text { 3.5-4.0 mm long; awn } 10-15 \\
\text { mm long, column ca. } 6 \mathrm{~mm} \\
\text { long }\end{array}$ & $\begin{array}{l}\text { 4.0-4.5 mm long; awn } 18 \\
-24 \mathrm{~mm} \text { long, column } 8 \text { - } \\
10 \mathrm{~mm} \text { long }\end{array}$ & $\begin{array}{l}\text { 3.5-4.0 mm long; awn } \\
\text { 14-16 mm long, column } \\
\text { 6-7 mm long }\end{array}$ \\
\hline $\begin{array}{l}\text { Pedicel of } \\
\text { pedicelled } \\
\text { spikelet }\end{array}$ & $\begin{array}{l}\text { Ca. } 2 \mathrm{~mm} \text { long, more than } \\
1 / 3 \text { rd length of lower glume } \\
\text { of sessile spikelet }\end{array}$ & $\begin{array}{l}1-1.5 \mathrm{~mm} \text { long, less than } \\
1 / 3 \text { rd length of lower } \\
\text { glume of sessile spikelet }\end{array}$ & $\begin{array}{l}2-2.5 \mathrm{~mm} \text { long, more } \\
\text { than } 1 / 3 \text { rd length of } \\
\text { lower glume of sessile } \\
\text { spikelet }\end{array}$ \\
\hline $\begin{array}{l}\text { Pedicelled } \\
\text { spikelets }\end{array}$ & $\begin{array}{l}\text { Rudimentary, with } \\
\text { rudimentary glumes without } \\
\text { lemma or if present smaller } \\
\text { in size }\end{array}$ & $\begin{array}{l}\text { Well developed with well } \\
\text { developed glumes and } \\
\text { lemmas }\end{array}$ & $\begin{array}{l}\text { Well developed with } \\
\text { well developed glumes } \\
\text { and lemmas }\end{array}$ \\
\hline $\begin{array}{l}\text { of pedicelled } \\
\text { spikelet }\end{array}$ & $\begin{array}{l}\text { Glumes rudimentary often a } \\
\text { small scale not winged }\end{array}$ & $\begin{array}{l}\text { Broadly winged on one } \\
\text { side and narrowly winged } \\
\text { on the other }\end{array}$ & $\begin{array}{l}\text { Narrowly winged on one } \\
\text { margin }\end{array}$ \\
\hline
\end{tabular}


lanceolate, margins scabrid, truncate at apex, hyaline, 2- nerved infolded along the nerves. Lodicules 2, 0.5- $0.8 \times 0.8-1.0 \mathrm{~mm}$, obovate, obliquely truncate and wavy at apex, broadly cuneate at base,hyaline.Stamens 3; filaments 2.5-3.5 mm long; anthers 1.8- $2.2 \mathrm{~mm}$ long, oblong, yellow. Ovary ca. $1.0 \times 0.4 \mathrm{~mm}$, ovoid; style 1.0-1.4 mm long; stigmas $1.5-2.0 \mathrm{~mm}$ long, feathery, purple. Grain 2- 2.5 × 1.0-1.2 mm, oblong-ellipsoid, obtusely trigonous, smooth, straw-coloured.

Flowering and fruiting: November - March.

Habitat and associated species: Ischaemum sreenarayanii was found to grow in abandoned paddy fields and other marshy localities in association with Hydrolea zeylanica (L.) Vahl., Isachne miliacea Roth., Ammania baccifera L., Fimbristylis littoralis Gaudich., Leersia hexandra Sw., Ludwigia hyssopifolia (G. Don) Exell etc.

Conservation status: The new species was observed in two localities with very few populations. The extent of occurrence is estimated to be about $34 \mathrm{~km}$ and distributed as isolated patches. This was found to grow in the wetlands near the road side; hence the chance for getting extinction is more. The human encroachment and developmental activities leads to the demolition of the natural habitat of this species. By following IUCN criteria (CR B1 ab (i,ii,iv); 2ab (i,ii,iv); D) for assessing the status of Rare and Threatened plants, Ischaemum sreenarayanii is assessed as belonging to Critically Endangered (CR) category (IUCN 2014).

Etymology: The species is named in the honour of the great saint and social reformer, Sree Narayana Guru, in whose name a number of educational institutions have been established all over Kerala.

Additional specimens examined (Paratype): India, Kerala: Palakkad District, Alathur, Padur \pm 16 m 22 November 2014, C.N. Sunil 4928 (SNMH!); Thrissur district, Kombazha $\pm 11,27$ January 2016, Remya \& Sunil 8237 (CMPR!).

\section{Acknowledgements}

The authors are thankful to the Principal \& Staff of the Department of Botany, S.N.M. College, Maliankara.

\section{References}

Dileep, P. and Geetha, G.N. 2015. I. kasaragodensis (Poaceae- Panicoideae), a new species from Western Ghats, India. Annals of Plant Sciences 4(10): 1199-1201.

IUCN 2014. IUCN Red List Categories and Criteria, ver. 3.1. - IUCN Species Survival commission.

Mabberley, D.J. 2008. The Plant Book. Cambridge University Press.

Nayar, T.S., Rasiya Beegam, A., Mohanan, N. and Rajkumar, G. 2006. Flowering Pants of Kerala. Tropical Botanical Garden and Research Institute, Thiruvananthapuram, India

Singh R.K. and Rao, P.S.N. 2008.Genus Ischaemum L. (Poaceae) In India. J. Econ. Taxon. Bot. 32(4): 797-835.

Sreekumar, P.V. and Nair, V.J. 1991. Flora of Kerala - Grasses. Botanical Survey of India, Calcutta. Srivastava, S.K and Nair, V.J. 2010. Genus Ischaemum L. (Poaceae) In India. Nelumbo 52: 63-92.

Sur, P.R. 2001. A Revision of the genus Ischaemum L. (Poaceae) in India. J. Econ. Taxon. Bot. 25: 407-438. The Plant List. 2013. Ver. 1.1. Published on the internet; http: //www.theplantlist.org/ accessed 28 July 2016.

Vinay, M.R., Rinku, J.D. and Veldcamp, J.F. 2011. I. sayajiraoi, a new species of Poaceae from Gujarat, India. Kew Bulletin 66: 303-306. 